\title{
AN EMPIRICAL STUDY TO DIAGNOSE THE OUTCOMES OF CUSTOMERS' EXPERIENCES IN TRENDY COFFEE SHOPS
}

\author{
Halil Nadiri' ${ }^{1}$, G. Nazan Gunay ${ }^{2}$ \\ ${ }^{1}$ Department of Business Administration, Eastern Mediterranean University, \\ P.O. Box 95 Gazimağusa, North Cyprus, Via Mersin-10, Turkey \\ ${ }^{2}$ Faculty of Economics and Administrative Sciences, Department of Business \\ Administration, Ege University, 35040 Bornova, İmir, Turkey \\ E-mails: ${ }^{1}$ halil.nadiri@emu.edu.tr (corresponding author); ${ }^{2}$ nazan.gunay@ege.edu.tr
}

Received 3 February 2011; accepted 10 October 2011

\begin{abstract}
The purpose of this study is to analyse the influence of experiential marketing on young customers' experiential values and respectively on their satisfaction and word of mouth and revisit intentions. An instrument was developed to measure how the strategic experiential module (Schmitt 1999) and service quality perceptions of customers influence their experiential values. Data were gathered through questionnaires conducted with 450 respondents to diagnose young customers' experiences in Gloria Jean's Coffees shops in North Cyprus. The structural equation modelling through partial least square (PLS) method results were acceptable in terms of reliability and validity. The empirical results revealed that, some of the strategic experiential modules and service quality perceptions have positive influences on customer experiences (functional and emotional). Results also show that customers' satisfaction can induce positive post purchase behaviour. The results, managerial implications, and suggestions for future research are discussed in detail.
\end{abstract}

Keywords: experiential marketing, service quality, experiential value, future buying intentions, young customers, Gloria Jean's Coffee.

Reference to this paper should be made as follows: Nadiri, H.; Gunay, G. N. 2013. An empirical study to diagnose the outcomes of customers' experiences in trendy coffee shops, Journal of Business Economics and Management 14(1): 22-53.

JEL classification: M31.

\section{Introduction}

Globalisation, intense competition, volatile consumer demands and changes both in economic and political systems force companies to learn faster and adopt themselves to environmental changes (Ginevičius, Gudačiauskas 2004). Some of the fastest growing sectors of the global economy are related to the consumption of experiences (Pine, Gilmore 1999). Today, providing experiences is seen as the way to remain competitive in markets where global competition and technology have turned products and services into commodities. Tourism has been at the forefront of staging experience, as Sternberg (1997: 952-954) succinctly put, "tourism primarily sells a staged experience... tour- 
ism's central productive activity is the creation of the touristic experience". Although experience is recognised as a major benefit offered by the hospitality and tourism industry, the use of experiential marketing in this industry is not well documented (Yuan, $\mathrm{Wu}$ 2008). Thus, this study aims to contribute improving hospitality and tourism operations by examining experiential marketing at a trendy coffee shop environment. The empirical research was carried out at one of the leading coffee shop chains, namely Gloria Jean's Coffee, in North Cyprus.

Furthermore, this study pays attention to carrying out this empirical research by focusing on young customers defined by Schewe and Meredith (2004) approximately 17-23 years of age.

During this stage of their lives young customers develop a subjective sense of identity through experimentation and explorations (Arnett 2000). Young customers are also able to influence the purchase and decision making of others through their increased independence and consumption sophistication (Loudon, Della Bitta 1993). During their years in higher education, students will develop many of their opinions and preferences which they will keep throughout their lives (Jenkinson 2000). The youth market is described in the literature as 'the consumer of the future' (Goldenberg 2005), 'agents of change' (Spero, Stone 2004) and as 'trend setting loyals' (Bakewell, Mitchell 2003). Businesses targeting the youth market need to understand this emerging behaviour to ensure that they meet the needs of this very discerning and influential group to ensure long term relationship and loyalty (Jenkinson 2000). Thus, the present study focuses on young customers such as the university students that come from various countries to North Cyprus to attend one of the six universities on the island. The economy of the island is heavily dependent on providing services to university students and businesses compete to get a larger share of this lucrative market through higher quality and innovative services.

Accordingly, the purpose of this study is to analyse the influence of experiential marketing on customers' value and customers' experiences and its impact on customers' satisfaction and post purchase intentions. The study uses the instrument developed by Schmitt (1999) to measure how strategic experiential module and service quality perceptions of customers influence their experiential values. The study examines customer value and customer experiences and test strategic experiential module on young customers in North Cyprus who visited Gloria Jean's shops in North Cyprus towns during the spring of 2009. In addition, the questionnaire included items to measure customers' service quality perceptions. The quality judgements of customers are most important, while all other judgements are essentially irrelevant (Parasuraman et al. 1991). As Parasuraman et al. (1985) argued, service quality perceptions of customers influence their overall experiences.

This empirical study is expected to make two important contributions to the marketing literature. First, the influence of experiential marketing on customer value, customers' experiential values impact on customers' satisfaction and post purchase intentions will be analysed. For this purpose experiential marketing performance was examined by measuring customers' perceptions. Fifteen hypotheses were developed to examine the 
relationship and data was analysed using partial least square (PLS) methodology. Second, the research will be conducted in an emerging market setting which is a growing touristic destination with its unique business culture, and idiosyncratic economic and political conditions. From a practical point of view, the outcomes of this research can be used by managers to gain an in-depth understanding of customer experiences and of the relationship among experiential marketing, experiential value, customers' satisfaction, word of mouth and revisit intentions. Such an understanding will assist managers for developing effective marketing strategies that will improve the operational environment and contribute to improving customers' perceived experiential value.

\section{Literature review}

\subsection{Experiential marketing}

The marketing concept has been a fundamental issue for organizations after Drucker (1954) stated that marketing is the unique function of business. The core concept of marketing is the creation of customer value for competitive advantage. The new challenge for the marketing concept is the development of experiential marketing to create firm-level competitive advantage. Intense competition around the world has lead companies to not just see the transformation of economic values from goods and services but, to stage experiences. Pine and Gilmore (1998) provided the fourth economic benefit as experience with the approach of "experience economy". According to Pine and Gilmore (1998), leading-edge companies will find that competitive battleground lies in staging experiences. "An experience occurs when a company intentionally uses services as the stage, and goods as props, to engage, individual customers in a way that creates a memorable event" (Pine, Gilmore 1998: 98). Pine and Gilmore (1998: 102-105) suggested five principles to create memorable experiences: a well-defined theme for the experience, positive cues for desired impression, elimination of negative cues for supporting positive cues, memorabilia for commemorating experiences and engaging all five sense for effective and memorable experiences. In further studies by the same authors (Pine, Gilmore 2000), companies are recommended to create customer surprise to uncover the fourth element in the progression of economic value. Gilmore and Pine (2002) highlighted the importance of experiences, for making marketing superfluous by creating distinct and unique economic value.

The ultimate aim of experiential marketing is to create memorable events by customizing goods and services to create customer - unique value (Pine, Gilmore 1999: 71). The "hospitality product" is an amalgam of tangible and intangible products and services factors. These factors are; "quality of service", "ambiance", "atmospherics" and "servicescape" (Pizam 2010: 343). Although there is sufficient empirical evidence to suggest that these factors are associated with increase guest satisfaction, repeat visitation and most importantly willingness to pay higher prices, companies try to adopt these factors to create memorable experiences to satisfy customers, because creating memorable experiences is the essence and raison d'étre of the hospitality industry (Pizam 2010: 343). The quality of experience is drive for customer satisfaction and willingness to pay high prices for hospitality products. Thus, the quality of the experience is the moderating 
or intervening variable between the independent variables of quantity and quality of tangible and intangible goods and services, and the dependent variables of customer satisfaction and willingness to pay high prices (Pizam 2010: 343).

Hence, the aim of the hospitality industry is to create memorable events by customizing goods and services to create unique customer value (Pine, Gilmore 1999), as Yuan and $\mathrm{Wu}$ (2008: 390) pointed out that creating unforgettable experiences is critical to the success of businesses in the hospitality industry. So, companies must create "quality of experiences" to drive customer satisfaction and willingness to pay high prices for hospitality "products" (Pizam 2010). "Quality of experience" (Pizam 2010) could explain "how successful businesses create repeat and loyal customers by providing unforgettable experiences" (Yuan, Wu 2008: 390).

Pine and Gilmore (1998) described the characteristics of experiences on the basis of two dimensions. The first dimension is customer participation (active/passive) which explains customers' roles in performance that yields the experiences. The second dimension is the connection (absorption/immersion) that unites customers with the performance. The experiences are divided into four categories on the basis of these two dimensions as entertainment, educational, esthetic and escapist experiences. Pine and Gilmore (1998) suggested that companies should create customer experience places as real or virtual venues where customers can have their own experiences. Companies are advised to render the authenticity on their messages to customers and to provide either real or virtual place to create place making experiences for customers to be perceived as real (Pine, Gilmore 2008). The types of experiences are identified by Brakus et al. (2009) as product, shopping and service, consumption and brand experiences. Although the authors approached that brand, experience affects consumer satisfaction and loyalty directly and indirectly through brand personality associations, the same outcomes could be assumed for each type of experiences. The concept of customer experience was investigated by scholars to find the ways to create, lead and how to offer a better understanding of customer experiences in conceptual approaches (Carbone, Haeckel 1994; Berry et al. 2002; Haeckel et al. 2003; Prahalad, Ramaswamy 2003; Crosby, Johnson 2007; Meyer, Schwager 2007; Pine, Gilmore 2008).

\subsection{Customers' experiential value}

Although the terms customer value and experiential value are used interchangeably, the difference between the two should be considered. Blattberg (1998) pointed out that customers are the most critical asset for businesses, so businesses should focus on long-term management of customer value and attract, develop, and maintain their relationships with their customers. Understanding what factors create customer value and trying to create a unique and creative customer value are necessary for retention of each business. Customer value has various definitions; while Monroe (1991) defined it as the comparison between recognized benefits and sacrifices, some others suggested that it is a combination of customers' belief, attitude and experience of product (Strauss, Frost 2002). What is certain and obvious from those definitions that customer value is the comparison between benefits and costs while customers are involved in a trade. 
Basically, the aim of experience economy is to create customer value. "The concept of customer value refers to subjective value perceived after an evaluation process, and developed by a balance between benefits and sacrifices" (Yuan, Wu 2009: 391). Customer value is also defined as a "relativistic preference characterizing a consumer's experience of interacting with some objects such as any good, service, thing, place, event or idea" (Kim 2002: 597). Customer value has two components: (i) emotional values and (ii) functional values. Functional value refers to financial or mental rewards that customers gain from products to customers, whereas emotional value refers to the feeling or emotional reaction that customers gain during and after experiencing (Yuan, Wu 2008: 392). Financial or mental rewards that customers get form their experience is functional value which can be measured by investigating factors such as effectiveness, convenience, shopping desirability and satisfactory price (Mathwick et al. 2001). In general, functional value can be considered a basic value delivered to customers (Berry et al. 2002; Schmitt 1999). Does the coffee taste good? Does the hotel provide a clean room and comfortable bed? Emotional value is the economic value or monetary worth of feelings when customers positively experience products and services (Barlow, Maul 2000). Customers' feelings and attitude toward some products, businesses, and brands constitute the emotional value in which the enjoyment of customers, return, relaxation, good feeling and satisfaction are the factors which are investigated in this study to measure emotional value (Sweeney, Soutar 2001). In other words, the feelings and emotional reactions that customers experience during or after experiences are emotional value (Berry et al. 2002; Schmitt 1999). In general, emotional value refers to the feeling or emotional reaction that customers gain during and after experiencing (Berry et al. 2002; Schmitt 1999). For example, does the waiter or server of the restaurant really care about customers? Does the tour guide have a passion to help people learn something (Yuan, Wu 2008: 392)?

Experiential value refers to customers' perceptions of products or services through direct use or indirect observation (Mathwick et al. 2001). Experiential value is defined as "interactions involving either direct usage or distanced appreciation of goods and services" and four dimensions of experiential value are offered as "customer return on investment, service excellence, playfulness and aesthetic appeal" (Mathwick et al. 2001: 41). Experiential value is important for ensuring customer satisfaction (Cronin et al. 2000; Ennew, Binks 1999; Kristensen et al. 2000) and offers customers extrinsic and intrinsic benefits (Batra, Ahtola 1991; Mano, Oliver 1993; Babin, Darden 1995). The intrinsic benefit is starting and finishing a task or a job, whereas the extrinsic benefit comprises the pleasure and happiness of completing a process (Babin et al. 1994). Furthermore, beside intrinsic/extrinsic dimension, Holbrook (1994) added a dimension, active/reactive, to experiential value. The active value comes from the increasing collaboration between customers and the business; the reactive value derives from customers' evaluations, responses, and understanding of the services or products they want to purchase.

As Yuan and Wu stated (2008) customer value and experiential value have many similarities. So, both customer and experiential value are accepted as inseparable and integral parts of the concept of value. Thus, measurement of experiential value used in 
this study is based on the measurement developed by Yuan and $\mathrm{Wu}$ (2008: 392) where it is conceptualized as "emotional and functional values are the main components of customer value".

Experiential marketing has become a contemporary concept used to understand complicated consumers needs and desires. The reason that experiential marketing has been championed as a new philosophy of marketing is that traditional marketing does not provide a broad point of view to understand consumers and to create better customer value any more. The main idea of experiential marketing is that it focuses on consumer experiences, consumption is treated as a holistic experience, recognises both traditional and emotional drivers of consumption, and uses eclectic methodologies. Schmitt (1999) approached experiential marketing based on the five different types of experiences, called strategic experiential modules that marketers can create to satisfy consumer needs: SENSE, FEEL, THINK, ACT and RELATE. The five different types of experiences explained as follows (Schmitt 1999: 61-62):

- SENSE marketing appeals to the senses with the objective of creating sensory experiences, through sight, sound, touch, taste and smell. SENSE marketing may be used to differentiate companies and products, to motivate customers and to add value to products (e.g., through aesthetics or excitement). One of the key principles of SENSE is "cognitive consistency/sensory variety," i.e., the ideal SENSE approach provides an underlying concept that is clearly detectable but appears always fresh and new.

- FEEL marketing appeals to customers' inner feelings and emotions, with the objective of creating affective experiences that range from mildly positive moods linked to a brand (e.g., for a non-involving, nondurable grocery brand or service or industrial product) to strong emotions of joy and pride (e.g., for a consumer durable, technology, or social marketing campaign). What is needed for FEEL marketing to work is a close understanding of what stimuli can trigger certain emotions as well as the willingness of the consumer to engage in perspective taking and empathy. Standard emotional advertising lacks both because it does not target feelings during consumption. It is difficult to create successful FEEL campaigns on an international scale because both the emotion-inducing stimuli and the willingness to empathize in a given situation often differ from culture to culture.

- THINK marketing appeals to the intellect with the objective of creating cognitive, problem-solving experiences that engage customers creatively THINK appeals to target customers' convergent and divergent thinking through surprise, intrigue and provocation. THINK campaigns are common for new technology products. But THINK marketing is not restricted only to high-tech products. THINK marketing has also been used in product design, retailing and in communications in many industries.

- ACT marketing enriches customers' lives by targeting their physical experiences, showing them alternative ways of doing things (e.g., in business-to-business and industrial markets), alternative lifestyles and interactions. Rational approaches to behaviour change (i.e., theories of reasoned actions) are only one of many behavioral change options. Changes in lifestyles and behaviors are often more motivational, 
inspirational and emotional in nature and often motivated by role models (such as movie stars or athletes).

- RELATE marketing contains aspects of SENSE, FEEL, THINK and ACT marketing. However, RELATE marketing expands beyond the individual's personal, private feelings, thus relating the individual to something outside his/her private state. RELATE campaigns appeal to the individual's desire for self-improvement (e.g., a future "ideal self that he or she wants to relate to"). They appeal to the need to be perceived positively by individual others (e.g., one's peers, girl friend, boy friend or spouse; family and colleagues). They relate the person to a broader social system (a subculture, a country, etc.).

- Experiential marketing has been studied in many areas such as retailing, branding, entertainment, online shopping, tourism, hospitality and art (Mathwick et al. 2001; Petkus 2004; Thompson, Arsel 2004; Bigne et al. 2005; Ho, Li, Su 2006; Tsaur et al. 2006; Williams 2006; Chang, Chieng 2006; Keng et al. 2007; Kao et al. 2008; Yuan, Wu 2008; Puccinelli et al. 2009). These studies have attempted to find links either between experiential marketing and branding or loyalty, or have analysed the strategic experiential modules in different applications.

In this empirical study, we attempt to build a conceptual model where functional and emotional values are stimulated by customers' perception of the strategic experiential modules (Berry et al. 2002) and by customers' perception of service quality. The literature review reveals that environmental factors like music (Hui et al. 1997), colour (Bellizzi et al. 1983), smell (Spangenberg et al. 1996) and level of crowding (Hui, Bateson 1991) all have created different customer responses. Thus, ten hypotheses were developed to test the relationships among experiential marketing (strategic experiential module) and experiential value.

H1: Sense perception causes positive emotional value.

H2: Sense perception causes positive functional value.

H3: Feel perception causes positive emotional value.

H4: Feel perception causes positive functional value.

H5: Think perception causes positive emotional value.

H6: Think perception causes positive functional value.

H7: Act perception causes positive emotional value.

H8: Act perception causes positive functional value.

H9: Relate perception causes positive emotional value.

H10: Relate perception causes positive functional value.

\subsection{Quality and experiential value}

Similar to service quality, experience quality is assumed to directly and significantly influence satisfaction (Caruana et al. 2000; Baker, Crompton 2000) and perceived value (Petrick, Backman 2002; Zeithaml 1988). The impact of perceived value on overall sat- 
isfaction has been depicted by many research studies (Woodruff 1997; Grönroos 1997; Cronin et al. 2000; Petrick, Backman 2002).

Parasuraman et al. (1985: 47) maintained that "perceived service quality is the result of customer's comparison of expected service with perceived service". Although there are many external and internal factors affecting service quality perception, these factors can not be generalized to all customers since service quality perception is subjective and depends on customers' individual experiences with the service they encounter. Perceived value is defined as the "consumer's overall assessment of the utility of a product based on perceptions of what is received and what is given" (Zeithaml 1988: 14). Perceived value can not be viewed as a trade-off between quality and price (Sweeney, Soutar 2001), as it is a broader concept and it involves social, emotional, functional, epistemic and conditional value as dimensions of consumption value (Sheth et al. 1991). The term perceived is reflected in the experiential view, in which it is believed that value judgment is dependent upon the consumers' experience (Nasution, Mavondo 2008). Perceived service quality is influenced by perceived value involving functional and emotional values. Rust et al. (2000) proposed that perceived value is influenced positively by perceived quality, while Oh (1999) suggested that service quality is an antecedent to customer value. Imrie et al. (2002) noted that service quality is an important antecedent of consumer assessments of value. Snoj et al. (2004) argued that perceived quality has a positive impact on perceived value. In a more recent study Choi et al. (2004) suggested that perceived service quality has a significant, positive, direct influence on value assessment. Thus, the influence of perceived service quality on functional and emotional values (experiential value) is tested in this study.

Also, the literature review shows that service quality affects customer value (Fornell et al. 1996; Cronin et al. 2000; Rust et al. 2000). Service quality is an antecedent to customer value (Oh 1999; Imrie et al. 2002) and is an important factor in influencing the value customers place on services (Sweeney et al. 1999). Perceived service quality has a significant, positive, direct influence value assessmen (Choi et al. 2004). So, two hypotheses are proposed to test the influence of perceived service quality on experiential value (functional and emotional).

H11: Service quality causes positive emotional value.

H12: Service quality causes positive functional value.

\subsection{Experiential value and customer satisfaction}

Literature on customer satisfaction illustrates that "expectations reflect anticipated performance made by customer about the levels of performance during a transaction" (Churchill, Suprenant 1982). Satisfaction is defined as an emotional post-consumption response that occurs as a result of comparing expected and actual performance (disconfirmation). Alternatively, it can be an outcome that occurs without comparing expectations (Oliver 1996). Moreover, "satisfaction is based on the extent to which customers perceive the service episode to have met, fallen short, or exceeded their expectations" (Nicholls et al. 1998). When the performance is less than expected, the organization ex- 
periences harm in its business image. When customers are satisfied, in other words when the expectations and performance are equivalent, the organization may be performing well. When customers are delighted, they may become loyal customers, and frequently become an organization's best advertising/marketing tool (Nicholls et al. 1998).

Customer satisfaction, furthermore, plays an important role in achieving customer loyalty and profitability (Barsky, Nash 2003). Therefore, it is crucial to know exactly how such satisfaction is measured. Many have been trying to measure customer satisfaction and have gathered plenty of data as a result. The problem is that measuring customer satisfaction does not provide any clues for achieving it. Customer satisfaction is essentially the culmination of a series of customer experiences or, one could say, the net result of the good ones minus the bad ones. It occurs when the gap between customers' expectations and their subsequent experiences is closed (Meyer, Schwager 2007).

Although relevant literature provides numerous perspectives for examining consumer value, experiential value and its effect on consumer satisfaction is rarely addressed (Wu, Liang 2009). Thus, this study follows this precedent by focusing on how experiential values of young customers affect their level of satisfaction in trendy coffee shops.

Among the few studies that addressed this issue is the study by Lee and Bang (2004) who proposed with regard to online shopping that consumer online shopping value (utilitarian and experiential value) positively influences consumer satisfaction. A second study by Gallarza and Gil-Saura (2006) proposed that perceived value is a direct antecedent of consumer satisfaction. Furthermore, Shieh and Cheng (2007) tested a consumer behavioural model of adolescent and young adult online gamers and proposed that experiential values positively impact satisfaction. Moreover, Sparks et al. (2007) found that consumer values positively and significantly correlate with satisfaction with timeshare product. Wu and Liang (2009) proposed that in luxury-hotel restaurants consumer experiential value positively influences consumer satisfaction.

Additional research findings have supported the relationship between perceived customer value and customer satisfaction (Cronin et al. 2000; Ennew, Binks 1999; Fornell et al. 1996; Kristensen et al. 2000; Patterson, Spreng 1997). Thus, two hypotheses relating to experiential value and customer satisfaction were developed to test the relationship between the two.

H13: Emotional value has positive effect on customer satisfaction.

H14: Functional value has positive effect on customer satisfaction.

\subsection{Customer satisfaction and post purchase intentions}

Related to customer satisfaction, as Parasuraman and Grewal (2000) defined, it is the evaluation and emotional recognition of whole purchasing processes after acquiring. As customers perceived that they made a good choice and that the product did satisfy their needs and wants, with the service that they expected, this will have a positive impact on their future buying intention. In other words, any dissatisfaction in any of determinants of customer satisfaction may reduce future buying intention of customers. 
Additionally, Venetis and Ghauri (2004) suggested that even if customers do not feel affective commitment, they would still be inclined to stay if their agency produces good quality work. It is, however, questionable whether the perceived quality as such is a sufficient motivation to maintain a relationship in the long term. If customers are not also affectively committed, the relationship will dissolve more easily once problems occur. Real customer loyalty originates from the part of service quality that contributes to customers' affective commitment (Venetis, Ghauri 2004). Foscht et al. (2009) have addressed the importance of personal interaction between store managers and customers. They observed that customers are more satisfied when they receive personal attention and they are more likely to recommend the stores they shop to others. Thus, personal attention has a positive impact on both customer satisfaction and customer loyalty. Furthermore, the positive influence on customer satisfaction of interaction between staff and customers was also indicated by Wu and Liang (2009).

Moreover, McDougall and Levesque (2000) pointed out the importance of perceived value for loyalty and, in turn, for profitability. It is well understood that increasing customer loyalty is positively correlated with increasing profitability. McDougall and Levesque (2000) indicated that the three factors - core service quality, relational service quality, and perceived value - all have impact on customer satisfaction, which, in turn, influences loyalty. Additionally, the existence of a quality - value satisfaction - loyalty chain relationship was confirmed by Gallarza and Gil-Saura (2006). Koening-Lewis and Palmer (2008) provided more evidence for the links between satisfaction, emotions, and future behavioural intentions.

The consequences of customer satisfaction in service industries are in the form of intention to recommend (word of mouth) and intention to repurchase/revisit. The latter leads to customer loyalty (Host, Knie-Anderson 2004). Thus, the present study considers the consequences of customer satisfaction as post purchase intention to be word of mouth and revisit intention.

\section{- Customer satisfaction and word of mouth}

Word of mouth (WOM) has attracted a great deal of attention among practitioners. WOM is one of the aspects of post purchase behavior and occurs as people keep on sharing their assessment of their experiences (Kim et al. 2009). For example several books tout WOM as a viable alternative to traditional marketing communication tools. One calls it "the world's most effective, yet least understood marketing strategy" (Minser 1999). Marketers are particularly interested in better understanding WOM as traditional forms of communication appear to be losing effectiveness (Forrester 2005). The importance of consumer WOM for service firms has been well established (Mangold et al. 1999). This study, attempts to predict how customers' service experience influence their customer satisfaction and consequently their WOM. When a service experience is particularly enjoyable and/or beneficial, consumers will be motivated to encourage their friends and family to participate in the behaviour.

Perceived service value affects both customer satisfaction and WOM. As functional and emotional values directly stimulate customer satisfaction, they may also indirectly 
affect WOM. Babin et al. (2005) have analysed customer satisfaction and WOM association from a different perspective that "personal shopping value" and "customer service value" are two constructs where two explain the key post-consumption outcomes including customer satisfaction and consumer WOM. The empirical study conducted by Lee, Yoon and Lee (2007) also supported the impact of perceived value on satisfaction and recommendations to others. Host and Knie-Anderson (2004) emphasized that price and service quality affects customer satisfaction and thus customer loyalty and willingness to recommend to other.

WOM communication that relates both to positive and negative evaluations of service encounters, has been shown to affect other people's purchase behavior. While positive WOM communication results from satisfactory service encounters, negative communication generally follows unsatisfactory encounters (Susskind 2002). Kim et al. (2009) observed that customer satisfaction and WOM among university student and full-time employees visiting university dining facilities are very strongly correlated and there is a positive significant relationship between customer satisfaction and WOM. Ranaweera and Prabhu (2003) confirmed that customer satisfaction have strong positive association with positive WOM. Thus, WOM has a positive relationship with customer satisfaction. In the case where customers are pleased by the choice of goods or services, they will have positive WOM which can have an enormous affect on potential and existing customers, hence we established another hypothesis to study the relationship between WOM and customer satisfaction.

H15: Customer satisfaction has positive effect on WOM.

\section{- Customer satisfaction and intention to revisit}

Purchase intentions refer to the degree of perceptual conviction of a customer to repurchase a particular product (good or service) or to repurchase any product (good or service) at a particular organization. The implicit assumption made by those who gather and analyse consumer intentions data is that such data will reflect future sales behaviours. Research in social psychology suggests that intentions are the best predictor of an individual behaviour because they allow each individual to independently incorporate all relevant factors that may influence the actual behavior. Armstrong et al. (2000) compared buying intentions with other sales forecasting tools. They found that purchase intentions represent an accurate measure of future sales and that it provides better forecasts than an extrapolation of past sales trends. The benefits of maintaining a base of long-term customers are widely recognized by marketers. Given that the cost of retaining an existing customer is less expensive than prospecting for a new customer (Spreng et al. 1995), purchase intention is a very important consideration for all organizations.

Some studies in food and beverage sector indicates that customer satisfaction is an important predictor of customer intent to return (Qu 1997; Pettijohn et al. 1997; Oh 2000; Weiss et al. 2005). Satisfaction, in turn, has been shown to be a reliable predictor of repurchase/revisit intention (LaBarbera, Mazursky 1983; Bitner 1990; Anderson, Sullivan 1993; Stevens et al. 1995; Patterson, Spreng 1997; Hui et al. 2007; Jang, Feng 2007; Kim et al. 2009). Thus, we developed a hypothesis to test the relationship between customer satisfaction and intention to revisit. 
H16: Customer satisfaction has positive effect on intention to revisit.

Based on the concepts explained above, experiential marketing stimulates experiential value and customer satisfaction. Concepts of experiential marketing and experiential value are further divided into several areas to be effectively measured. Experiential marketing is measured by sense perception, feel perception, think perception, and service quality; experiential value is measured by emotional value and functional value.

\section{Research methodology}

The present study focuses on university students as young customers and research was carried out in North Cyprus during the spring of 2009. The economy of the island is heavily dependent on services, and North Cyprus in particular has a multicultural consumer market as a result of the large number of students with respect to population of North Cyprus (around 280,000 inhabitants) who attend the six universities here. Therefore, the sample of the study consists of university students enrolled in these six universities. There are around 48,000 students receiving higher education in these universities. $68 \%$ of them are from Turkey, $22 \%$ are local students and rest $(10 \%)$ is from other countries. Other than national coffee shops, Gloria Jean's is the only international coffee shop chain that operates in North Cyprus.

A self-reported questionnaire was developed to test the relationships among the four main concepts: experiential marketing, experiential value, customer satisfaction and post purchase behavior.

The questionnaire was developed in both English and Turkish. A pilot study was then conducted with a sample of 30 respondents. The final questionnaire includes 22 statements (adopted from Parasuraman et al. 1988; Schmitt 1999; Chang, Chieng 2006) to measure perceptions of young customers about their experiential marketing experiences. Five statements were adopted from Brady and Cronin (2001) to measure service quality perceptions, and to measure perceptions about experiential values 5 statements used for emotional values which were adopted from Sweeney and Soutar (2001), and four statements used for functional values which were adopted from Mathwick et al. (2001), Sweeney and Soutar (2001). In order to identify satisfaction of respondents three items are used, based on measures commonly used in satisfaction research, using one five-point Likert scale and two five-point bipolar adjective scales (adopted from Oliver, Swan 1989). Revisit intentions were measured on three five-point bipolar adjective scales (Fishbein, Ajzen 1975; Oliver, Swan 1989). The WOM intentions (WOM) were assessed using three items (adopted from Babin et al. 2005). Finally, the questionnaire also included questions regarding certain demographic characteristics of the respondents (gender, age, nationality and total monthly income of family). Respondents were asked to use a five-point Likert-type scale (where 5-point scales anchored $1=$ "strongly disagree" and $5=$ "strongly agree") to record their perceptions. The interviews were conducted by trained interviewers who applied the questionnaire to chosen respondents within the coffee shops. Questionnaires were distributed at two Gloria Jean's Coffees 
shops in North Cyprus. Samples were selected on the basis of a non-probability convenience sampling technique (Aaker et al. 1995). A total of 485 questionnaires were collected; 35 were partially completed or unusable and excluded from data entry. Thus, 450 questionnaires were used for the data analysis. The usable rate was $92.78 \%$.

Data analysis was performed by using Partial Least Squares (PLS) and structural equation modelling (SEM) tool (Smart-PLS 2.0 M3). SEM permits a simultaneous assessment of the structural component (path model) and measurement component (factor model) in one model. One of the SEM techniques is the PLS, a well-established technique for estimating path coefficients in structural models and has been widely used in various research studies (for example, Chin et al. 1996; Wixon, Watson 2001; Ashill et al. 2005; Zhang 2009). The PLS technique has become increasingly popular in information systems research, marketing and in management research more generally in the last decade because of its ability to model latent constructs under conditions of non-normality and small to medium sample sizes (Chin 1998).

SEM is a multivariate technique combining aspects of multiple regression and factor analysis to estimate a series of interrelated dependence relationship simultaneously. This simultaneity is important since the measures often receive their meaning from the conceptual network within which they are embedded. Actually, this is not the case with standard path analysis nor with regression analysis, where the measures are first tested before application to the structural equations (Bagozzi, Yi 1988).

\section{Results}

- Respondents' demographic profile

A demographic breakdown of the sample shows that $64 \%$ of the respondents were males and $36 \%$ were females. As for the age distribution, $29.3 \%$ respondents fall between the age group of " $17-20$ ", $52.9 \%$ were between " $21-24$ " and $17.7 \%$ were above the age of 25 . In terms of nationality $63.8 \%$ were Turkish, $25.1 \%$ were local students, and $11.1 \%$ were from various other countries. The $57.1 \%$ of respondents have monthly family income between "1000-2500" USD, 8.2\% have monthly family income less than 1000 USD and $34.6 \%$ have monthly family income more than 2500 USD.

\section{- Measurement}

In Table 1 the means and standard deviations of the composite measures of the model constructs are presented. Frequency analysis of the 45 items indicated no problems of floor or ceiling effects in the measurements. The usable response number $(n=450)$ also exceeded the recommended minimum required for model estimation. PLS requires a minimum sample size (Chin 1998) that equals 10 times the greater of (a) the number of items comprising the most complex formative construct or (b) the largest number of predictors leading to an endogenous construct. In this study, the most complex regression involved six predictors leading to the endogenous construct, experiential value, thus indicating that the minimum sample requirement for statistical analysis is sixty usable responses. 
Table 1. Convergent and discriminant validity of the model construct

Variable

Factor Loading

\section{Customer Satisfaction}

$$
\text { ic }=0.92 \quad \text { Factor mean score }=3.63 \quad \alpha=0.86 \quad \mathrm{SD}=0.845 \quad \mathrm{AVE}=0.78
$$

SAT1

SAT2

SAT3

\section{Word of Mouth Communication}

\begin{tabular}{lllrr}
\hline ic $=0.77$ & Factor mean score $=3.51$ & $\alpha=0.77$ & SD $=0.950$ & AVE $=0.55$ \\
WI1 & & & \\
WI2 & & & 0.875 \\
WI3 & & & 0.829 \\
& & 0.886
\end{tabular}

\section{Intention to Revisit}

\begin{tabular}{lllll}
\hline ic $=0.95$ & Factor mean score $=3.60$ & $\alpha=0.92$ & SD $=0.948$ & AVE $=0.86$ \\
I1 & & & \\
I2 & & & 0.938 \\
I3 & & & 0.943 \\
& & & 0.908
\end{tabular}

\section{Emotional Value}

\begin{tabular}{|c|c|c|c|c|}
\hline $\mathrm{ic}=0.90$ & Factor mean score $=3.63$ & $\alpha=0.86$ & $\mathrm{SD}=0.801 \quad \mathrm{AVE}=0.64$ & \\
\hline EV1 & & & & 0.773 \\
\hline EV2 & & & & 0.823 \\
\hline EV3 & & & & 0.832 \\
\hline EV4 & & & & 0.843 \\
\hline EV5 & & & & 0.738 \\
\hline
\end{tabular}

\section{Functional Value}

\begin{tabular}{lllll}
\hline ic $=0.89$ & Factor mean score $=3.03$ & $\alpha=0.84$ & SD $=1.033$ & AVE $=0.68$ \\
FV1 & & & & 0.810 \\
FV2 & & & & 0.862 \\
FV3 & & & 0.822 \\
FV4 & & & 0.793 \\
Sense & & $\alpha=0.78$ & SD $=0.544$ & AVE $=0.53$ \\
\hline ic $=0.84$ & Factor mean score $=3.83$ & & & \\
SV1 & & & & 0.665 \\
SV2 & & & & 0.635 \\
SV3 & & & & 0.598 \\
SA4 & & & & 0.634 \\
\hline
\end{tabular}


End of Table 1

\begin{tabular}{lr}
\hline Variable & Factor \\
Loading
\end{tabular}

\section{Feel}

\begin{tabular}{lllll}
\hline ic $=0.86$ & Factor mean score $=3.75$ & $\alpha=0.75$ & SD $=0.759$ & AVE $=0.67$ \\
F9 & & & \\
F10 & & & & 0.874 \\
F11 & & & 0.854 \\
& & & 0.713
\end{tabular}

Think

$\begin{array}{lllll}\text { ic }=0.86 & \text { Factor mean score }=2.95 & \alpha=0.78 & \mathrm{SD}=0.839 & \mathrm{AVE}=0.60 \\ \mathrm{~T} 12 & & & & 0.722 \\ \mathrm{~T} 13 & & & 0.697 \\ \mathrm{~T} 14 & & & 0.827 \\ \mathrm{~T} 15 & & & 0.852\end{array}$

Act

ic $=0.93 \quad$ Factor mean score $=2.83 \quad \alpha=0.89 \quad \mathrm{SD}=1.046 \quad \mathrm{AVE}=0.82$

$\begin{array}{ll}\text { A16 } & 0.893\end{array}$

$\begin{array}{lr}\text { A17 } & 0.922\end{array}$

$\begin{array}{ll}\text { A18 } & 0.900\end{array}$

Relate

\begin{tabular}{llrrr}
\hline ic $=0.88$ & Factor mean score $=3.20$ & $\alpha=0.82$ & $\mathrm{SD}=0.893$ & AVE $=0.65$ \\
R19 & & & \\
R20 & & & 0.712 \\
R21 & & & 0.780 \\
R22 & & & 0.863 \\
& & & 0.857
\end{tabular}

Service Quality

\begin{tabular}{|c|c|c|c|c|}
\hline ic $=0.88$ & Factor mean score $=3.73$ & $\alpha=0.83$ & $\mathrm{SD}=0.793 \quad \mathrm{AVE}=0.60$ & \\
\hline SQ1 & & & & 0.766 \\
\hline SQ2 & & & & 0.757 \\
\hline SQ3 & & & & 0.831 \\
\hline SQ4 & & & & 0.784 \\
\hline SQ5 & & & & 0.725 \\
\hline
\end{tabular}

Notes: "ic" is international consistency measure; " $\alpha$ " is Cronbach's alpha; "AVE" is average variance extracted. 
In order to have model estimation, usable data has been analyzed by using Partial Least Square (PLS) methodology (Smart-PLS 2.0 M3). The test of the measurement model includes the estimation of the internal consistency and the convergent and discriminant validity of the instrument items. The composite reliability measure of internal consistency and the Average Variance Extracted (AVE) are two measures used to assess the composite reliability of a block of indicators measuring the construct. The internal consistency measure is similar to Cronbach's alpha as a measure of internal consistency except the latter presumes, a priori, that each indicator of a construct contributes equally. Cronbach's alpha assumes parallel measures, and represents a lower bound of composite reliability (Chin 1998). The internal consistency measure, which is unaffected by scale length, is more general than Cronbach's alpha, but the interpretation of the obtained values is similar and the guidelines offered by Nunnally (1978) can be adopted. All reliability measures were above the recommended level of 0.70 (see Table 1), thus indicating adequate internal consistency (Nunnally 1978). The Average Variance Extracted scores (AVE) were also above the minimum threshold of 0.5 (Chin 1998) and vary from 0.53 to 0.86 .

Convergent validity measures the degree to which items on a scale are in theory linked. A common rule-of-thumb is a loading greater than 0.7 (Chin 1998). In this case, all items loaded on their constructs from 0.71 to 0.94 indicating convergent validity.

Adequate discriminant validity was tested by exploring the average variance shared between a construct and its measures (AVE). Fornell and Larcker (1981) recommended values higher than 0.50 . Measures are also considered to have adequate discriminant validity if the square root of the average variance extracted for each construct is larger than the correlation between the construct and any other construct in the model. The pattern supports our scale and all constructs in the estimated model fulfilled this condition as it may follow from Table 2. Thus, the revised measurement model results provided support for the reliability, and convergent and discriminant validities of the measures used in the study.

Partial Least Square (PLS) makes no distributional assumptions in its parameter estimation procedure. Traditional parameter-based techniques for significance testing and model evaluation are considered to be inappropriate (Chin 1998). Smart PLS provides the $\mathrm{R}^{2}$ for each endogenous construct in the model and the path coefficients. $\mathrm{R}^{2}$ (Table 3 ) indicate the percentage of a construct's variance in the model, whilst the path coefficients indicate the strengths of relationships between constructs. In a manner consistent with Chin (1998) Bootstrapping (1000 resamples) was applied to produce standard errors and t-statistics. This allowed us to measure the statistical significance of the path coefficients. The results in Table 3 show that the structural model explains $56.4 \%$ of the variance in the emotional value construct and $29.8 \%$ of the variance in the functional value construct. As it can be seen from results, all strategic experiential modules have significant positive effect on emotional value other than the "think" module. Thus, H1, $\mathrm{H} 3, \mathrm{H} 7$ and $\mathrm{H} 9$ are supported, while H5 is not. For functional value, while "think", "act" and "relate" modules have significant positive effects, on functional value other modules do not. Thus, $\mathrm{H} 2$ and $\mathrm{H} 4$ are not supported, while H6, H8 and $\mathrm{H} 10$ are confirmed. Service quality dimension has a significant positive effect on both emotional and functional values. So, H11 and H12 are supported. 


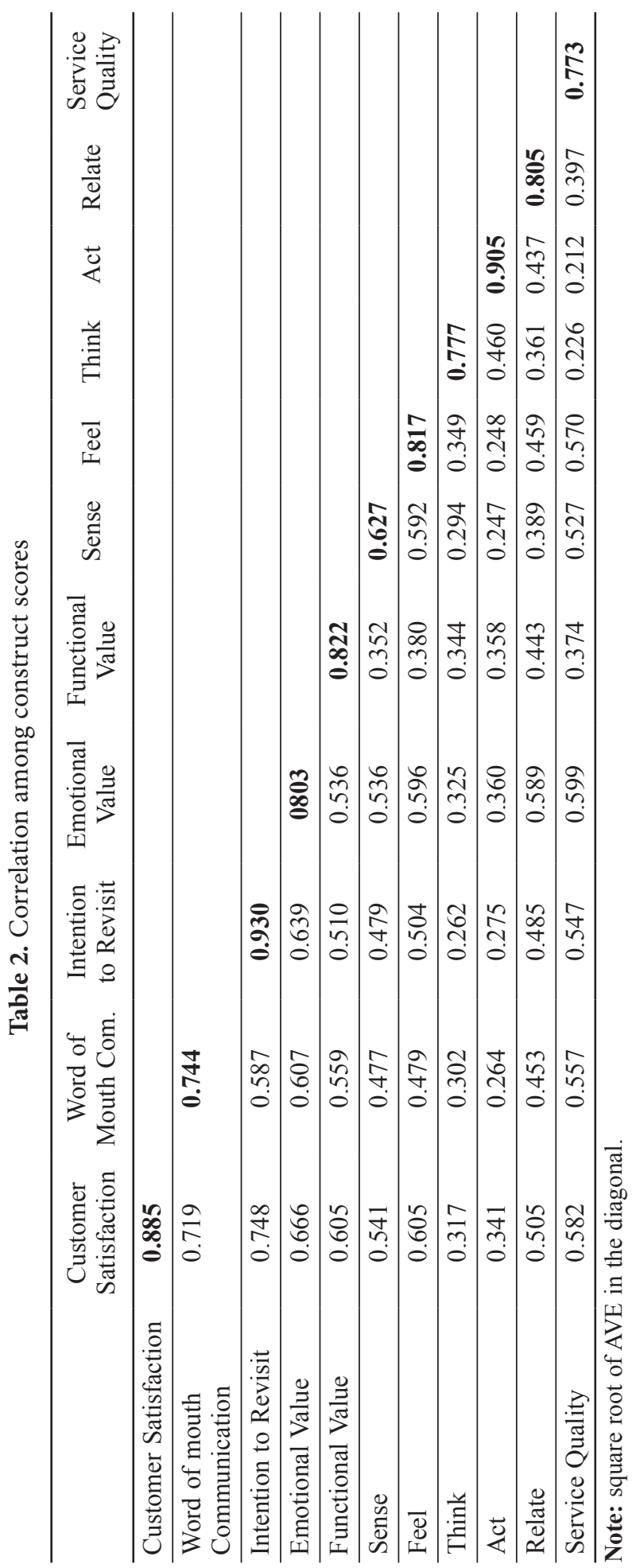


Table 3. Structural model results

\begin{tabular}{|c|c|c|c|c|}
\hline Effect on emotional value(R-Square 0.564 ) & $\begin{array}{l}\text { Proposed } \\
\text { Effect }\end{array}$ & $\begin{array}{c}\text { Path } \\
\text { Coefficient }\end{array}$ & $\begin{array}{l}\text { Observed } \\
\text { T-value }\end{array}$ & Significance \\
\hline H1. Sense & + & 0.1336 & 2.2922 & $0.02 *$ \\
\hline H3. Feel & + & 0.1993 & 4.0524 & $0.00 *$ \\
\hline H5. Think & + & 0.0076 & 0.2245 & 0.82 \\
\hline H7. Act & + & 0.0859 & 2.2922 & $0.02 *$ \\
\hline H9. Relate & + & 0.2944 & 8.107 & $0.00 *$ \\
\hline H11. Service quality & + & 0.2782 & 6.3695 & $0.00 *$ \\
\hline \multicolumn{5}{|l|}{ Effect on functional value (R-Square 0.298) } \\
\hline H2. Sense & + & 0.0756 & 1.4478 & 0.15 \\
\hline H4. Feel & + & 0.0748 & 1.3506 & 0.18 \\
\hline H6. Think & + & 0.1206 & 2.4266 & $0.02 *$ \\
\hline H8. Act & + & 0.1389 & 2.871 & $0.00^{*}$ \\
\hline H10. Relate & + & 0.2159 & 4.0105 & $0.00 *$ \\
\hline H12. Service quality & + & 0.1492 & 2.7959 & $0.01 *$ \\
\hline \multicolumn{5}{|c|}{ Effect on customer satisfaction (R-Square 0.530 ) } \\
\hline H 13. Emotional value & + & 0.4793 & 10.9143 & $0.00^{*}$ \\
\hline H 14. Functional value & + & 0.3482 & 8.0158 & $0.00^{*}$ \\
\hline \multicolumn{5}{|l|}{ Effect on WOM Com. (R-Square 0.517) } \\
\hline H 15. Customer satisfaction & + & 0.7193 & 26.0079 & $0.00 *$ \\
\hline \multicolumn{5}{|l|}{ Effect on intention to revisit (R-Square 0.559) } \\
\hline H 16. Customer satisfaction & + & 0.7476 & 30.7551 & $0.00^{*}$ \\
\hline
\end{tabular}

Note: $*$ p-values $<0.05$.

The structural model results also reveal that young customers' experiential value perceptions have a significant positive effect on their level of satisfaction. Thus, H13 and H14 are supported. With regard to the extend to which young customers' level of satisfaction is associated with their post purchase behavior, the structural model results demonstrate a significant positive relationship between customer satisfaction and positive word of mouth communication and intention to revisit. Therefore, support exists for both H15 and H16. Among the model's sixteen hypotheses thirteen are supported (Figure 1).

\section{Discussion}

A structural model was proposed to explore the influence of experiential marketing on customers' value and customers' experiences and its impact on customers' satisfaction and post purchase intentions in a coffee chain in North Cyprus. 


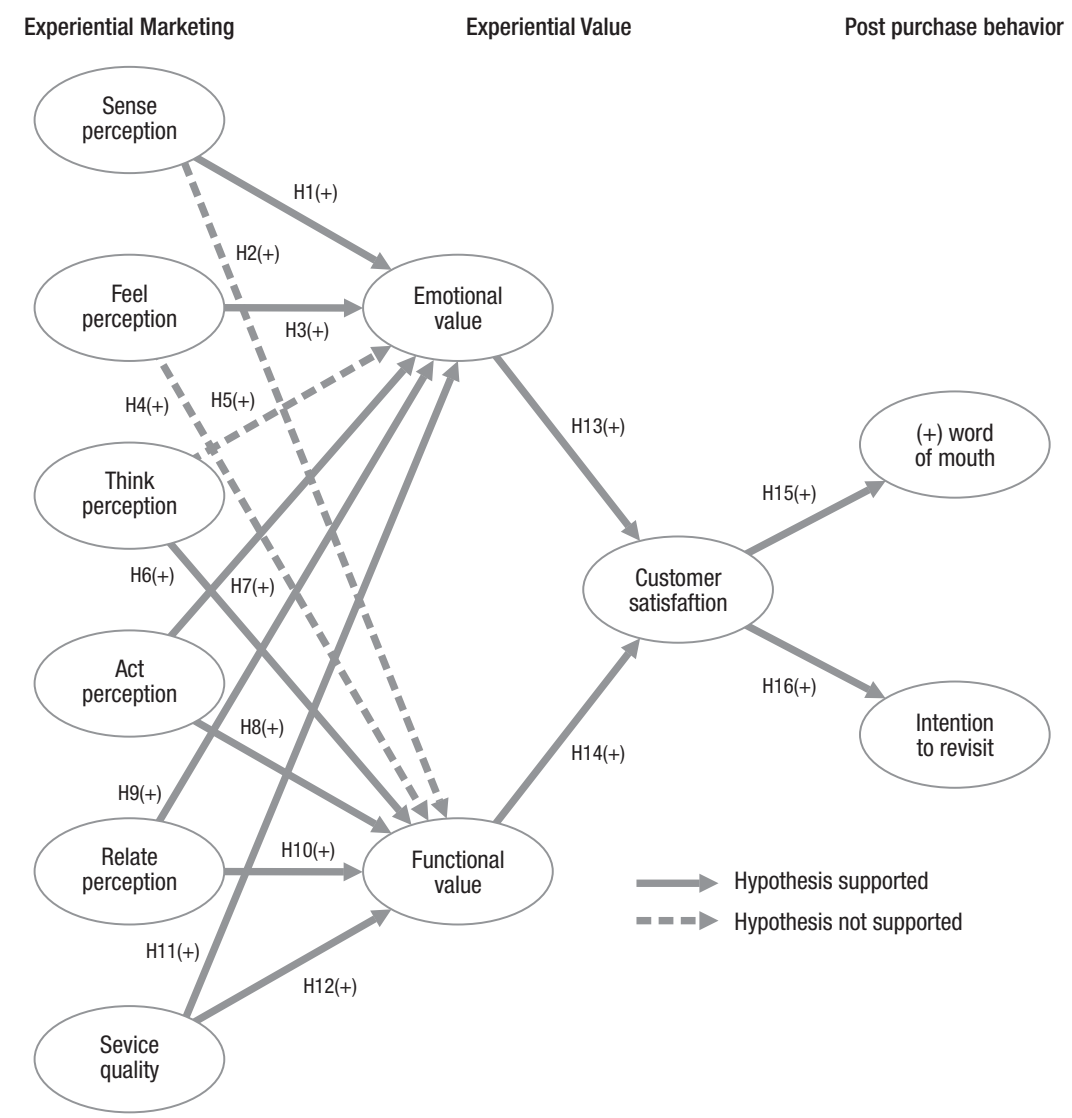

Fig. 1. Structural model

First, all strategic experiential modules are observed to have significant positive effect on emotional value other than the "think" module. The outcome on think perception is not consistent with Yuan and Wu (2008). It might be assumed that "think" perception has no effect on emotional value due to regular visits of customers to Gloria Jean's. Therefore, customers might not need to follow communication strategies of the shop since they visit the shop very often.

Additionally, it might be reason that Gloria Jean's is the only international coffee chain in North Cyprus and young customers enjoy being in this coffee as they might see it is a privilege for them to be customers of the unique international brand name in the island. Therefore, the coffee shop is very popular against its domestic rivals and activities or news related to Gloria Jean's are always a part of communication among the young customers in North Cyprus. So, the customers do not need to spend special effort to follow the news and communication materials of the coffee.

With regard to functional value, while "think", "act" and "relate" modules have significant positive effect, others do not have significant effect on functional value. The results in this study are somewhat consistent with the results of previous studies as far 
as functional value is concerned. The reason why sense and feel modules do not affect functional value might be due to the fact that café offers customers such relaxing and intimate atmosphere, unique decoration, tasteful products that are good value for their money. Being in a nice environment and being treated well by the staff could be assumed by customers as the benefits of the high price they pay. Also a study that carried out in North Cyprus find out that especially younger consumers have lower ethnocentric tendencies and they are ready to pay higher prices for foreign products (Nadiri, Tümer 2010). Gloria Jean's is the only international coffee chain in North Cyprus and there is no close international substitute for it, so this might be the reason why customers are ready to pay higher prices. Thus, it is not possible to generalise these findings, as it might be unique for North Cyprus.

The outcome of sense perception is consistent with Yuan and Wu (2008), it is not supported by other researchers (Areni, Kim 1993; Bellizzi et al. 1983). Additionally as Yuan and $\mathrm{Wu}(2008)$ approached for sense perception, repeat customers may not pay too much attention to the decoration, furniture, music, tastes and freshness of products, or layout of the store because they are familiar with the establishment. Since the functional value generally explains the value offered by the Gloria Jean's for the money customers pay (return on money), sense perception might not affect the functional value that customers have willingness to pay high prices in return of memorable experiences (Pizam 2010). The outcome of feel perception is again consistent with Yuan and $\mathrm{Wu}$ (2008). It could be explained that feel perception that does not affect functional value due to quality of experience customers offered to customers by Gloria Jean's derives customer satisfaction and customers are quite happy despite high prices of the coffee shop (Pizam 2010).

We conclude that strategic experiential modules have partially positive effects on emotional and functional values which influence customer satisfaction. Second, service quality dimension has a significant positive effect on both the emotional and the functional values. This result is supported by literature review and empirical studies (Fornell et al. 1996; Cronin et al. 2000; Rust et al. 2000; Oh 1999; Imrie et al. 2002; Sweeney et al. 1999; Choi et al. 2004). The results also reveal that young customers' experiential value perceptions have a significant positive effect on their level of satisfaction. This result is supported by Wu and Liang (2009).

According to a rule of thumb about the strength of correlation coefficient (Hair et al. 2000), both emotional and functional values have strong positive correlations with customer satisfaction which confirm the findings of other researchers (Cronin et al. 2000; Yuan, Wu 2008). This means that Gloria Jean's can achieve higher customer satisfaction through by experiential values that it creates by improving its' experiential marketing efforts and the service quality perceptions of customers.

The level of satisfaction of the customers positively affects their word of communication about Gloria Jean's and the customers' intentions to revisit the shop. These results are also consistent with the literature. The correlation results indicate that customer satisfaction has a strong positive correlation with post purchase behavior of respondents (Hair et al. 2000). In other words, satisfied customers have higher levels of intention for 
revisiting Gloria Jean's stores and their satisfaction levels induce them to provide positive word of mouth communication. These are very important outcomes of experiential marketing efforts that need to be considered by managers in service industry.

According to the general results provided by the structural model adopted by this study, strategic experiential module has partially positive effects on both functional and emotional value, while service quality has a significant positive effect on experiential value (functional and emotional). Consequently, experiential value perceptions of customers affect positively customers' satisfaction and post purchase behavior.

The results of hypothesis testing show that several paths of this model were supported. Sense, feel, act and relate perceptions and service quality affect customer satisfaction by means of emotional value. Think, act and relate perceptions and service quality affect customer satisfaction by means of functional value. From another point of view, act and relate perceptions and service quality affect customer satisfaction through emotional and functional value. The results also reveal that relate perception and service quality have stronger affects than others who have effects on experiential values because relate and service quality have larger coefficients in the model. Another important finding was customer satisfaction, which, through strategic experiential modules and service quality by means of experiential value, affects customers' positive word of mouth and intention to revisit. Thus, act and relate perceptions and service quality are very important factors when a company attempts to implement experiential marketing to achieve customer satisfaction and consequently positive post purchase behavior.

\section{Conclusion and implications}

The structural model was proposed to explore the influence of experiential marketing on customers' experiential values and respectively on their satisfaction and word of mouth and revisit intentions. Overall, our measurement results were acceptable in terms of reliability and validity. The PLS analysis provides support for interpretation relative to other techniques such as correlation and regression, since all of the relationships in PLS analysis, including those in the measurement model as well as the structural model, are tested simultaneously.

Results of this study showed that 13 of the 16 hypotheses are supported. The outcomes of the analyses suggest that experiential marketing efforts of businesses contribute to have positive customer experiences which could lead to customer satisfaction and consequently to induce positive post purchase behavior among young customers since Hypotheses 1, 3, 6, 7, 8, 9, 10, 11, 12, 13, 14, 15 and 16 were supported. Thus, strategic experiential modules and service quality causes customer satisfaction through experiential value (emotional and functional value) that provided by sense, feel, act, and relate perceptions and service quality on emotional value, while think, act, and relate perceptions and service quality on functional value. Overall both emotional and functional values have positive effect on customer satisfaction and customer satisfaction can induce positive word of mouth communication and intention to revisit among young customers. 
This means that managers need to provide customers with relax environment in which people can enjoy while they are spending part of their day in which they need to be far from tense and out environment. Pleasure which has been given to customer leads to revisit and better WOM. In this situation there will be win-win situation in which both customers will be satisfied and the enterprise will have a strong image in the mind of customers.

Though customers are willing to pay a lot for having good experiences but one can that high price may lead to dissatisfaction. This should be a concern for Gloria Jean's Coffees. As a result in order to bring both emotional and functional value to customers, the café should has a pleasurable environment beside its reasonable prices specially for country like North Cyprus where the main concentration is on students which they are sensitive on value. This will lead to a higher customer satisfaction and WOM. Consequently customers will become loyal, and café can enjoy from more customers and cross-selling.

It is noteworthy to remember that, although modern marketing focuses on experiential part, but the product itself and its quality have an important role in satisfaction. So, the quality of Gloria Jean's Coffees products such as its coffees, sandwiches and its confectionary products should have a high quality, since a relax environment with inferior products is meaningless.

The managers of café have to do their best to understand the needs and want of their users. Moreover, managers should ensure that personnel are completely oriented regard to the level of the service that should be performed. Training program is a recommended way to improve the staff's qualifications. In addition managers should continuously monitor the perception of customers regarding their products, and their latest needs and wants to keep their marketing tools updated. By this way they keep their customers more satisfied and delighted.

It is certain that Gloria Jean's as an international brand showed vital effort to create an appropriate environment for their customers through experiential marketing efforts. Although both emotional and functional values have positive effect on customer satisfaction, results of this research imply that think perceptions of customers may not be an important factor to influence customers' emotional values while sense and feel perceptions may not be important factors for customers' functional values. The research results about Gloria Jean's might be considered by other researchers as appropriate as other hospitality operations.

The management of Gloria Jean's in North Cyprus should consider the strength of the associations between variables and take necessary actions to build stronger associations between variables that have significant positive effect on customers' experiential values. The Gloria Jean's coffee is the only international chain that operates in North Cyprus. The rivals are all national coffee shops. Thus, especially among the university students this coffee shop is very popular. The customers have positive attitudes towards this coffee shop and a higher tendency to tolerate. In other words, being the only international 
brand should not be misleading to the management and the management should do their best to improve experiential value of customers that will lead to higher customer satisfaction and consequently post purchase behavior. The overall results of this study reveal that consumption is a holistic concept, and that experiential marketing can induce experiential value that has positive effect on customer satisfaction (Fornell et al. 1996; Cronin et al. 2000; Choi et al. 2004), thus, the managers in hospitality should focus on strategic experiential module and service quality to increase overall customer satisfaction.

It is apparent that all businesses need to gain and maintain a competitive advantage if they are to survive in this highly competitive global market. To do so, management must recognise that experiential marketing is a crucial marketing tool. Managers should frequently assess their customers' level of experiences and develop appropriate policies to meet their customers' expectations. The assumptions which mangers believed in, i.e. that their customers are rational and make decisions based on functional product features are not entirely valid today. Managers should take account of the unique experiences of their customers and implement experiential marketing strategies. From a practical point of view, the outcomes of this research can be used by managers to gain in-depth understanding of customer experiences, and develop effective marketing strategies that will improve the operational environment and thus contribute to improving customers' perceived experiential value.

This study results support the theory that experiential marketing practices and service quality lead customer satisfaction through experiential value and customer satisfaction induce positive post purchase behavior. There is no study exist in the literature that reported the synergistic effects of experiential marketing, experiential value and customer satisfaction simultaneously contribute to customers' post purchase behavior. Thus, this study might act as the basis for further studies regarding strategic experiential modules and post purchase behaviors. This study also contributes for managers by providing them a new look at experiential marketing and offering empirical supports to implement experiential marketing strategies.

Further research could be conducted in different café chains, in the same café chain in different countries or in different sub-sectors in hospitality. The results should be compared to gain a general outcome of the model proposed in this study. Also future research can focus on how experiential values of customers influence customer satisfaction and effect of customer satisfaction on buying intentions of customers.

The generalization of outcomes and conclusions drawn from this study is limited by the representativeness of the sample where non-probabilistic sampling method and convenience sampling were used. Data used in this research were collected from two Gloria Jean's in North Cyprus and all the respondents were university students. Consequently, it may be difficult to adopt the findings to other customer segments, industries, or countries. The proposed structural equation model does not consider the moderating role of demographic variables which consider being a subject of further studies. 


\section{References}

Aaker, D. A.; Kumar, V.; Day, G. S. 1995. Marketing Research. $5^{\text {th }}$ ed. New York: John Wiley. Anderson, E. W.; Sullivan, M. W. 1993. The antecedents and consequences of customer satisfaction for firms, Marketing Science 12(2): 125-143. http://dx.doi.org/10.1287/mksc.12.2.125

Areni, S. C.; Kim, D. 1993. The influence of background music on shopping behavior: classical versus top-forty music in a wine store, Advances in Customer Research 20(1): 336-340.

Armstrong, J. S.; Morwitz, V. G.; Kumar, V. 2000. Sales forecasts for existing consumer products and services: do purchase intentions contribute to accuracy?, International Journal of Forecasting 16(3): 383-397. http://dx.doi.org/10.1016/S0169-2070(00)00058-3

Arnett, J. J. 2000. Emerging adulthood: a theory of development from the late teens through the twenties, American Psychologist 55(5): 469-480. http://dx.doi.org/10.1037/0003-066X.55.5.469

Ashill, N. J.; Carruthers, J.; Krisjanous, J. 2005. Antecedents and outcomes of service recovery performance in a public health-care environment, Journal of Services Marketing 19(5): 293-308. http://dx.doi.org/10.1108/08876040510609916

Babin, B. J.; Darden, W. R.; Griffin, M. 1994. Work and/or fun: measuring hedonic and utilitarian shopping value, Journal of Consumer Research 20(4): 644-656. http://dx.doi.org/10.1086/209376

Babin, B. J.; Darden, W. R. 1995. Consumer self-regulation in a retail environment, Journal of Retailing 71(1): 47-70. http://dx.doi.org/10.1016/0022-4359(95)90012-8

Babin, B. J.; Lee, Y.; Kim, E, Griffin, M. 2005. Modeling consumer satisfaction and word-ofmouth: restaurant patronage in Korea, Journal of Service Marketing 19(3):133-139.

http://dx.doi.org/10.1108/08876040510596803

Bagozzi, R. P.; Yi, Y. 1988. On the evaluation of structural equation models, Journal of the Academy of Marketing Science 16(2): 74-94. http://dx.doi.org/10.1007/BF02723327

Baker, D. A.; Crompton, J. L. 2000. Quality, satisfaction and behavioral intentions, Annals of Tourism Research 27(3): 785-804. http://dx.doi.org/10.1016/S0160-7383(99)00108-5

Bakewell, C.; Mitchell, V. W. 2003. Generation Y female consumer decision-making styles, International Journal of Retail and Distribution Management 13(2): 95-106.

http://dx.doi.org/10.1108/09590550310461994

Barlow, J.; Maul, D. 2000. Emotional Value: Taking Customer Service to a New Level. San Francisco, CA: Berrett-Koehler.

Barsky, J.; Nash, L. 2003. Customer satisfaction: applying concepts to industry-wide measures, Cornell Hotel and Restaurant Administration Quarterly 44(5-6): 173-183. http://dx.doi. org/10.1016/S0010-8804(03)90122-4

Batra, R.; Ahtola, O. T. 1991. Measuring the hedonic and utilitarian sources of consumer attitudes, Marketing Letter 2(2): 159-170. http://dx.doi.org/10.1007/BF00436035

Bellizzi, J. A.; Crowley, A. E.; Hasty, R. W. 1983. The effects of color in store design, Journal of Retailing 59(1): 21-45.

Berry, L. L.; Carbone, L. P.; Haeckel, S. H. 2002. Managing the total customer experiences, MIT Sloan Management Review (Spring): 85-89.

Bigne, J. E.; Andreu, L.; Gnoth, J. 2005. The theme park experience: an analysis of pleasure, arousal and satisfaction, Tourism Management 26: 833-844.

http://dx.doi.org/10.1016/j.tourman.2004.05.006

Bitner, M. J. 1990. Evaluating service encounters: the effects of physical surroundings and employee responses, Journal of Marketing 54(2): 69-82. http://dx.doi.org/10.2307/1251871

Blattberg, R. C. 1998. Managing the firm using lifetime-customer value, Chain Store Age 74(1): 46. 
Brady, M. K.; Cronin, J. J. 2001. Customer orientation: effects on customer service perceptions and outcome behaviors, Journal of Service Research 3(3): 241-251.

http://dx.doi.org/10.1177/109467050133005

Brakus, J. J.; Schmitt, B. H.; Zarantonello, L. 2009. Brand experience: what is it? How is it measured? Does it affect loyalty?, Journal of Marketing 73(3): 52-68.

http://dx.doi.org/10.1509/jmkg.73.3.52

Carbone, L. P.; Haeckel, S. H. 1994. Engineering customer experiences, Marketing Management 3(3): 9-19.

Caruana, A.; Money, A.; Berthon, P. 2000. Service quality and satisfaction - the moderating role of value, European Journal of Marketing 34(11/12): 1338-1352.

http://dx.doi.org/10.1108/03090560010764432

Chang, P. L.; Chieng, M. H. 2006. Building consumer-brand relationship: a cross-cultural experiential view, Psychology \& Marketing 23(11): 927-959. http://dx.doi.org/10.1002/mar.20140

Chin, W.; Marcolin, B.; Newsted, P. 1996. A partial least squares latent variable modeling approach for measuring interaction effects: results from a Monte Carlo simulation study and voice mail emotion/adoption study, in 17th International Conference on Information Systems, Cleveland, 16-18 December, 21-41.

Chin, W. 1998. The partial least squares for structural equation modeling, in G. A. Marcoulides (Ed.). Modern Methods for Business Research. Mahwah, New Jersey: Erlbaum, 295-336.

Choi, K.; Cho, W. H.; Lee, S.; Lee, H.; Kim, C. 2004. The relationships among quality, value, satisfaction and behavioral intention in health care provider choice: a South Korean study, Journal of Business Research 57: 913-921. http://dx.doi.org/10.1016/S0148-2963(02)00293-X

Churchill, G. A.; Suprenant, C. 1982. An investigation into the determinants of consumer satisfaction, Journal of Marketing Research 19(4): 491-504. http://dx.doi.org/10.2307/3151722

Cronin, J. J.; Brady, M. K.; Hult, G. T. M. 2000. Assessing the effects of quality, value, and customer satisfaction on consumer behavioral intentions in service environments, Journal of Retailing 76(2): 193-218. http://dx.doi.org/10.1016/S0022-4359(00)00028-2

Crosby, L. A.; Johnson, S. L. 2007. Experience required, Marketing Management July-August: 20-28.

Drucker, P. 1954. The Principles of Management. New York, NY: Harper Collins Publishers.

Ennew, C. T.; Binks, M. R. 1999. Impact of participative service relationships on quality, satisfaction and retention: an exploratory study, Journal of Business Research 46(2): 121-132.

http://dx.doi.org/10.1016/S0148-2963(98)00016-2

Fishbein, M.; Ajzen, I. 1975. Belief, Attitude, Intention and Behavior: an Introduction to Theory \& Research. Reading, MA: Addison Wesley.

Fornell, C.; Johnson, M. D.; Anderson, E. W.; Cha, J.; Bryant, B. E. 1996. The American customer satisfaction index: nature, purpose, and findings, Journal of Marketing 60(4): 7-18. http://dx.doi.org/10.2307/1251898

Fornell, C.; Larcker, D. F. 1981. Structural equation models with unobservable variables and measurement error: algebra and statistics, Journal of Marketing Research 18(3): 382-388.

http://dx.doi.org/10.2307/3150980

Forrester Research. 2005 [online]. What's the buzz on word-of-mouth marketing? Social computing and consumer control put momentum into viral marketing (May). Available from Internet: http://www.forrester.com

Foscht, T.; Maloles, C.; Schloffer, J.; Swoboda, B.; Chia, S. L. 2009. Exploring the 1mpact of customer satisfaction on food retailers' evolution: managerial lessons from Austria, Journal of International Food \& Agribusiness Marketing 21(1) : 67-82.

http://dx.doi.org/10.1080/08974430802480669 
Gallarza, M. G.; Gil-Saura, I. G. 2006. Value dimensions, perceived value, satisfaction and loyalty: an investigation of university students' travel behaviour, Tourism Management 27(3): 437-452. http://dx.doi.org/10.1016/j.tourman.2004.12.002

Gilmore, J. H.; Pine, J. B. 2002. Customer experience places: the new offering frontier, Strategy and Leadership 30(4): 4-11. http://dx.doi.org/10.1108/10878570210435306

Goldenberg, B. 2005. The consumer of the future, Customer Relationship Management 9(5): 22.

Ginevičius, R.; Gudačiauskas, D. 2004. Brand valuation model, Journal of Business Economics and Management 5(3): 143-153.

Grönroos, C. 1997. Relationship marketing; communication, Journal of Business \& Industrial Marketing 19(2): 99-113.

Haeckel, S. H.; Carbone, L. P.; Berry, L. L. 2003. How to lead the customer experience, Marketing Management 12(1): 18-23.

Hair, J. F.; Bush, R. P.; Ortinau, D. J. 2000. Marketing Research: a Practical Approach for the New Millennium. Singapore: McGraw-Hill Int. Edition.

Ho, Y. C.; Li, Y. C.; Su, T. H. 2006. A discussion of refractive medical behavior from an experiential marketing viewpoint, Journal of Hospital Marketing \& Public Relations 16(1/2): 45-67. http://dx.doi.org/10.1300/J375v16n01_05

Holbrook, M. B. 1994. The nature of customer value: an axiology of services in the consumption experience, in R. T. Rust, R. L. Oliver (Eds.). Service Quality: New Direction in Theory and Practice. Newbury Park, CA: Sage, 21-71.

Host, V.; Knie-Andersen, M. 2004. Modeling customer satisfaction in mortgage credit companies, The International Journal of Bank Marketing 22(1): 26-42.

http://dx.doi.org/10.1108/02652320410514915

Hui, M.; Dubé, L.; Chebat, J. C. 1997. Impact of music on consumers' reactions to waiting for service, Journal of Retailing 73(1): 87-104. http://dx.doi.org/10.1016/S0022-4359(97)90016-6

Hui, M.; Bateson, J. 1991. Perceived control and the effects of crowding and consumer choice on the service experience, Journal of Consumer Research 18(2): 174-184.

http://dx.doi.org/10.1086/209250

Hui, T. K.; Wan, D.; Ho, A. 2007. Tourists' satisfaction, recommendation and revisiting Singapore, Tourism Management 28(4): 965-975. http://dx.doi.org/10.1016/j.tourman.2006.08.008

Imrie, B. C.; Cadogan, J. W.; McNaughton, R. 2002. The service quality construct on a global stage, Managing Service Quality 12(1): 10-18. http://dx.doi.org/10.1108/09604520210415353

Jang, S. C.; Feng, R. 2007. Temporal destination revisit intention: the effects of novelty seeking and satisfaction, Tourism Management 28(2): 580-590.

http://dx.doi.org/10.1016/j.tourman.2006.04.024

Jenkinson, E. 2000. Carry on campus, Checkout (2): 20-21.

Kao, Y. F.; Huang, L. S.; Wu, C. H. 2008. Effects on theatrical elements on experiential quality and loyalty intentions for theme parks, Asia Pacific Journal of Tourism Research 13(2): 163-174. http://dx.doi.org/10.1080/10941660802048480

Keng, C. J.; Huang, T. L.; Zheng, L. J.; Hsu, M. K. 2007. Modelling service encounters and customer experiential value in retailing, International Journal of Service Industry Management 18(4): 349-367. http://dx.doi.org/10.1108/09564230710778137

Kim, W. G.; Nee, C. Y.; Kim, Y. 2009. Influence of institutional DINESERV on customer satisfaction, return intention, and word-of-mouth, International Journal of Hospitality Management 28(1): 10-17. http://dx.doi.org/10.1016/j.ijhm.2008.03.005 
Kim, Y. K. 2002. Consumer value: an application to mall and internet shopping, International Journal of Retail \& Distribution Management 30(11/12): 595-602.

http://dx.doi.org/10.1108/09590550210453075

Koenig-Lewis, N.; Palmer, A. 2008. Experiential values over time - a comparison of measures of satisfaction and emotion, Journal of Marketing Management 24(1-2): 69-85.

http://dx.doi.org/10.1362/026725708X273920

Kristensen, K.; Martensen, A.; Gronholdt, L. 2000. Customer satisfaction measurement at Post Denmark: results of application of the European Customer Satisfaction Index Methodology, Total Quality Management 11(7): 1007-1015. http://dx.doi.org/10.1080/09544120050135533

LaBarbera, P. A.; Mazursky, D. 1983. A longitudinal assessment of consumer satisfaction/dissatisfaction: the dynamic aspect of the cognitive process, Journal of Marketing Research 20(4): 393-404. http://dx.doi.org/10.2307/3151443

Lee, C. K.; Yoon, Y. S.; Lee, S. K. 2007. Investigation the relationships among perceived value, satisfaction, and recommendations: the case of the Korean DMZ, Tourism Management 28(1): 204-214. http://dx.doi.org/10.1016/j.tourman.2005.12.017

Lee, C. S.; Bang, S. B. 2004. The effects of shopping value on online purchasing intention: focus on product attribute importance as intervening variables, Korean Marketing Research 19(2): 41-69.

Loudon, D. L.; Della Bitta, A. J. 1993. Consumer Behaviour: Concepts and Applications. New York: McGraw Hill.

Mangold, W. G.; Miller, F.; Brockway, G. R. 1999. Word-of-Mouth communication in the service marketplace, Journal of Services Marketing 13(1): 73-89.

http://dx.doi.org/10.1108/08876049910256186

Mano, H.; Oliver, R. L. 1993. Assessing the dimensionality and structure of the consumption experience: evaluation, feeling, and satisfaction, Journal of Consumer Research 20(3): 451-466. http://dx.doi.org/10.1086/209361

Mathwick, C.; Malhotra, N.; Rigdon, E. 2001. Experiential value: conceptualization, measurement and application in the catalogue and internet shopping environment, Journal of Retailing 77(1): 39-56. http://dx.doi.org/10.1016/S0022-4359(00)00045-2

McDougall, G. H. G.; Levesque, T. 2000. Customer satisfaction with services: putting perceived value into equation, Journal of Service Marketing 14(5): 392-410.

http://dx.doi.org/10.1108/08876040010340937

Meyer, C.; Schwager, A. 2007. Understanding customer experience, Harvard Business Review (2): 117-126.

Minser, I. R. 1999. The World's Best Known Marketing Secret: Building Your Business with Word-of-Mouth Marketing. $2^{\text {nd }}$ ed. Austin, TX: Brad Press.

Monroe, K. B. 1991. Pricing: Making Profitable Decisions. New York: McGraw Hill.

Nadiri, H.; Tümer, M. 2010. Influence of ethnocentrism on consumers' intention to buy domestically produced goods: an empirical study in North Cyprus, Journal of Business Economics and Management 11(3): 444-461.

Nasution, H. N.; Mavondo, F. T. 2008. Customer value in the hotel industry: what managers believe they deliver and what customer experience, International Journal of Hospitality Management 27(2): 204-213. http://dx.doi.org/10.1016/j.ijhm.2007.02.003

Nicholls, J. A. F.; Gilbert, G. R.; Roslow, S. 1998. Parsimonious measurement of customer satisfaction with personal service and the service setting, Journal of Consumer Marketing 15(3): 239-253. http://dx.doi.org/10.1108/07363769810219116 
Nunnally, J. C. 1978. Psychometric Theory. New York: McGraw-Hill.

Oh, H. 2000. Diners' perception of quality, value, and satisfaction: a practical viewpoint, Cornell Hotel and Restaurant Administration Quarterly 41(3): 58-66.

http://dx.doi.org/10.1177/001088040004100317

Oh, H. 1999. Service quality, customer satisfaction, and customer value: a holistic perspective, International Journal of Hospitality Management 18(1): 67-82.

http://dx.doi.org/10.1016/S0278-4319(98)00047-4

Oliver, R. L.; Swan, J. E. 1989. Consumer perceptions of interpersonal equity and satisfaction in transactions: a field survey approach, Journal of Marketing 53(2): 21-35.

http://dx.doi.org/10.2307/1251411

Oliver, R. L. 1996. Assessing the dimensionality and structure of the consumption experience: evaluation, feeling, and satisfaction, Journal of Consumer Research 20(3): 451-466.

Parasuraman, A.; Berry, L. L.; Zeithaml, V. A. 1991. Understanding customer expectations of service, Sloan Management Review 32(3): 39-48.

Parasuraman, A.; Grewal, D. 2000. The impact of technology on the quality-value-loyalty chain: a research agenda, Journal of the Academy of Marketing Science 28(1): 168-174.

http://dx.doi.org/10.1177/0092070300281015

Parasuraman, A.; Zeithaml, V. A.; Berry, L. L. 1985. A conceptual model of service quality and its implications for future research, Journal of Marketing 49(Fall): 41-50.

http://dx.doi.org/10.2307/1251430

Parasuraman, A.; Zeithaml, V. A.; Berry, L. L. 1988. SERVQUAL: a multiple-item scale for measuring consumer perceptions of service quality, Journal of Retailing 64(1): 12-40.

Patterson, P. G.; Spreng, R. A. 1997. Modeling the relationship between perceived value, satisfaction and repurchase intentions in a business-to-business, services context: an empirical examination, International Journal of Service Industry Management 8(5): 414-434.

http://dx.doi.org/10.1108/09564239710189835

Petkus, E. Jr. 2004. Enhancing the application of experiential marketing in the arts, International Journal of Nonprofit and Voluntary Sector Marketing 9(1): 49-56.

http://dx.doi.org/10.1002/nvsm.232

Petrick, J. R.; Backman, S. J. 2002. An examination of golf travelers' satisfaction, perceived value, loyalty, and intentions to revisit, Tourism Analysis 6(3): 223-237.

Pettijohn, L. S.; Pettijohn, C. E.; Luke, R. H. 1997. An evaluation of fast food restaurant satisfaction: determinants, competitive comparisons, and impact on future patronage, Journal of Restaurant and Foodservice Marketing 2(3): 3-20. http://dx.doi.org/10.1300/J061v02n03_02

Pine, J. B.; Gilmore, J. H. 1998. Welcome to the experience economy, Harvard Business Review (July-August): 97-105.

Pine, J. B.; Gilmore, J. H. 1999. The Experience Economy: Work is Theatre and Every Business a Stage. Boston, MA: Harvard Business School Press.

Pine, J. B.; Gilmore, J. H. 2000. Satisfaction, sacrifice, surprise: three small steps create one giant leap into the experience economy, Strategy and Leadership 20(1): 18-23.

Pine, J. B.; Gilmore, J. H. 2008. Keep it real, Marketing Management (January-February): 18-24.

Pizam, A. 2010. Creating memorable experiences, International Journal of Hospitality Management 29(3): 343. http://dx.doi.org/10.1016/j.ijhm.2010.04.003

Prahalad, C. K.; Ramaswamy, V. 2003. The new frontier of experience innovation, MIT Sloan Management Review 44(4): 12-18.

Puccinelli, N. M.; Goodstein, R. C.; Grewal, D.; Price, R.; Raghubir, P.; Stewart, D. 2009. Customer experience management in retailing: understanding the buying process, Journal of Retailing 85(1): 15-30. http://dx.doi.org/10.1016/j.jretai.2008.11.003 
Qu, H. 1997. Determinant factors and choice intention for Chinese restaurant dining: a multivariate approach, Journal of Restaurant and Foodservice Marketing 2(2): 35-49.

http://dx.doi.org/10.1300/J061v02n02_03

Ranaweera, C.; Prabhu, J. 2003. On the relative importance of customer satisfaction and trust as determinants of customer retention and positive word of mouth, Journal of Targeting, Measurement and Analysis for Marketing 12(1): 82-90. http://dx.doi.org/10.1057/palgrave.jt.5740100

Rust, R. T.; Danaher, P. J.; Varki, S. 2000. Using service quality data for competitive marketing decisions, International Journal of Service Industry Management 11(5): 438-469.

http://dx.doi.org/10.1108/09564230010360173

Schewe, C. D.; Meredith, G. 2004. Segmenting global markets by generational cohorts: determining motivations by age, Journal of Consumer Behaviour 4(1): 51-63.

http://dx.doi.org/10.1002/cb.157

Schmitt, B. 1999. Experiential marketing, Journal of Marketing Management 15: 53-67. http://dx.doi.org/10.1362/026725799784870496

Sheth, J. N.; Newman, B. I.; Gross, B. I. 1991. Why we buy what we buy a theory of consumption values, Journal of Business Research 22: 159-170.

http://dx.doi.org/10.1016/0148-2963(91)90050-8

Shieh, K. F.; Cheng, M. S. 2007. An empirical study of experiential value and lifestyle and their effects on satisfaction in adolescents: an example using online gaming, Adolescence 42(165): 199-215.

Snoj, B.; Korda, A. P.; Mumel, D. 2004. The relationships among perceived quality, perceived risk and perceived product value, Journal of Product \& Brand Management 13(3): 156-167. http://dx.doi.org/10.1108/10610420410538050

Spangenberg, E. R.; Crowley, A. E.; Henderson, P. W. 1996. Improving the store environment: do olfactory cues affect evaluations and behaviours?, Journal of Marketing 60(2): 67-80.

http://dx.doi.org/10.2307/1251931

Sparks, B. A.; Butcher, K.; Pan, G. 2007. Understanding customer-derived value in the timeshare industry, Cornell Hotel and Restaurant Administration Quarterly 48(1): 28-45.

http://dx.doi.org/10.1177/0010880406294473

Spero, I.; Stone, M. 2004. Agents of change: how young consumers are changing the world of marketing, Qualitative Market Research: An International Journal 7(2): 153-159.

Spreng, R. A.; Harrell, G.; Mackoy, R. D. 1995. The impact of service recovery efforts on consumer intentions, Journal of Services Marketing 9(1): 15-23.

http://dx.doi.org/10.1108/08876049510079853

Sternberg, E. 1997. The iconography of the tourism experience, Annals of Tourism Research 24(4): 951-969. http://dx.doi.org/10.1016/S0160-7383(97)00053-4

Stevens, P.; Knutson, B.; Patton, M. 1995. DINESERV: a tool for measuring service quality in restaurants, Cornell Hotel and Restaurant Administration Quarterly 36(2): 56-60.

http://dx.doi.org/10.1177/001088049503600226

Strauss, J.; Frost, R. 2002. E-marketing. $3^{\text {rd }}$ ed. Upper Saddle River, NJ: Prentice Hall.

Susskind, A. 2002. I told you so: restaurant customers' word-of-mouth communication patterns, Cornell Hotel and Restaurant Administration Quarterly 43(2): 75-85.

http://dx.doi.org/10.1016/S0010-8804(02)80034-9

Sweeney, J. C.; Soutar, G. N. 2001. Consumer perceived value: the development of a multiple item scale, Journal of Retailing 77(2): 203-220. http://dx.doi.org/10.1016/S0022-4359(01)00041-0

Thompson, C. J.; Arsel, Z. 2004. The Starbucks branscape and consumers (anticorporate) experiences of globalization, Journal of Consumer Research (December): 631-642.

http://dx.doi.org/10.1086/425098 
Tsaur, S. H.; Chiu, Y. T.; Wang, C. H. 2006. The visitor behavioral consequences of experiential marketing: an empirical study on Taipei zoo, Journal of Travel and Tourism Marketing 21(1): 47-64. http://dx.doi.org/10.1300/J073v21n01_04

Weiss, R.; Feinstein, A. H.; Dalbor, M. 2005. Customer satisfaction of theme restaurant attributes and their influence on return intent, Journal of Foodservice Business Research 7(1): 23-42.

http://dx.doi.org/10.1300/J369v07n01_03

Venetis, K. A.; Ghauri, P. N. 2004. Service quality and customer retention: building long-term relationships, European Journal of Marketing 38(11): 1577-1598.

http://dx.doi.org/10.1108/03090560410560254

Williams, A. 2006. Tourism and hospitality marketing: fantasy, feeling and fun, International Journal of Contemporary Hospitality Management 18(6): 482-495.

http://dx.doi.org/10.1108/09596110610681520

Wixon, B.; Watson, H. 2001. An empirical investigation of the factors affecting data warehousing success, MIS Quarterly 25(1): 17-41. http://dx.doi.org/10.2307/3250957

Woodruff, R. B. 1997. Customer value: the next source for competitive advantage, Journal of the Academy of Marketing Science 25(2): 139-153. http://dx.doi.org/10.1007/BF02894350

Wu, C. H.; Liang, R. 2009. Effect of experiential value on customer satisfaction with service encounters in luxury-hotel restaurants, International Journal of Hospitality Management 28(4): 586-593. http://dx.doi.org/10.1016/j.ijhm.2009.03.008

Yuan, Y. H.; Wu, C. 2008. Relationships among experiential marketing, experiential value and customer satisfaction, Journal of Hospitality \& Tourism Research 32(3): 387-410.

http://dx.doi.org/10.1177/1096348008317392

Zeithaml, V. A. 1988. Consumer perceptions of price, quality, and value: a means-end model and synthesis of evidence, Journal of Marketing 52(3): 2-22.

http://dx.doi.org/10.2307/1251446

Zhang, Y. 2009. A Study of corporate reputation's influence on customer loyalty based on PLSSEM Model, International Business Research 2(3): 28-35. 


\section{APPENDIX}

\section{Items from the Questionnaire}

\section{Sense}

SV1. Gloria Jean's coffee shops have visually attractive products

(coffees, sandwiches, cookies)

SV2. Materials associated with the service (such as pamphlets/statements, menus)

are visually appealing and attention getting at Gloria Jean's coffee shops

SV3. The internal and external decoration of Gloria Jean's coffee shops is attractive and attention getting

SA4. The auditory (music) system offers relaxing and pleasant atmosphere

SS5. There is a nice and interesting smell with in Gloria Jean's coffee shops

ST6. The tastes of the products match my expectation

STO7. The products offered for eating are fresh

STO8. Furnitures are clean and comfortable

\section{Feel}

F9. I feel myself comfortable and happy at this café

F10. Café has relaxing and intimate atmosphere

F11. I feel during my conversations' with Gloria Jean's coffee shops staff, they pay enough attention to my expectations

\section{Think}

T12. These cafés organize different activities that take my attention

T13. There are print and visual channels of communication and Internet connection within this cafe that makes me to follow up daily developments

T14. I follow the latest news about Gloria Jean's Coffee shops from their web site

T15. I follow up the news which takes place in media about Gloria Jean's coffee shops

\section{Act}

A16. This coffee shop tries to make me think about lifestyle

A17. This coffee shop tries to remind me of activities I can do

A18. This coffee shop gets me to think about my behavior

\section{Relate}

R19. This coffee shop helps me to develop relationship with my social environment

R20. My friends that I share the same social environment prefer this coffee shop, so this makes me to prefer this coffee shop as well

R21. Be a customer of Gloria Jean's is one of the activities of social class that I belong to

R22. At Gloria Jean's I feel myself that I am in the right place that I should be in

\section{Service Quality}

SQ1. This café performs the service right the first time

SQ2. I feel safe in my transactions with this café

SQ3. This café provides its service at the time it promises to do so 
SQ4. Employees of this café insists on to fully understand what I want

SQ5. Employees are neat appearing

\section{Emotional Value}

EV1. I enjoy being in this café

EV2. This café makes me to revisit it

EV3. In this café I feel myself relax

EV4. This café makes me feel good

EV5. Being in this café gives me pleasure

\section{Functional Value}

FV1. In this café products are reasonably priced

FV2. This café offers value for money (return of my money)

FV3. In this café I receive good product for the price that I pay for

FV4. This café is being economical.

\section{Word of Mouth Communication}

WI1. I will say positive things about this café to other people

WI2. I will recommend it to someone who seeks my advice

WI3. I will encourage friends and relatives to visit the café

\section{Satisfaction}

SAT1. I am satisfied with my decision to get some products/visit here

SAT2. Taking everything into consideration, how do you feel about this café

SAT3. Taking everything into consideration, how do you feel about this café

\section{Intention To Revisit}

I1. In your future decisions would you plan to revisit this café?

I2. In your future decisions would you plan to revisit this café?

I3. In your future decisions would you plan to revisit this café?

Halil NADİRI. Professor of Marketing in the Department of Business Administration, Eastern Mediterranean University, Famagusta, North Cyprus. He has BBA, MBA and PhD in Marketing. He has authored many articles, book chapters and conference papers about marketing, service quality, customer and employee satisfaction. Dr Nadiri has many board memberships and Presidential positions in different institutes. He is also currently Vice Rector of Eastern Mediterranean University in charge of Promotion and University Advancement. His current research interests are; service quality and customer satisfaction, experiential marketing, justice perceptions and related issues.

G. Nazan GÜNAY. Professor of Marketing at Ege University Faculty of Economics and Administrative Sciences, Department of Business Administration. She received PhD degree from UMIST, School of Management, Manchester, UK. Her research interests are market orientation, consumer behaviour, experiential marketing. 